\title{
PERGESERAN PANDANGAN TERHADAP \\ NILAI SOSIAL BUDAYA DALAM MASYARAKAT \\ SEBAGAI AKIBAT PENGARUH KEBUDAYAAN
}

\author{
KOESNO WARDOJO \\ PENDIDIKAN EKONOMI IKIP PGRI Madiun
}

\begin{abstract}
Asbtrak:
Perubahan sosial budaya masyarakat selalu terjadi setiap saat, sejalan dengan perkembangan, kemajuan serta perubahan masyarakat itu sendiri, fenomena yang terjadi dalam masyarakat dengan adanya perubahan sosial budaya sebagai akibat pengaruh kebudayaan akan timbul gejolak, riak kecil dalam masyarakat. Dalam menanggapi perubahan tersebut sebagian masyarakat dapat menerima sepenuhnya, ada yang menerima dengan seperuh hati dan bahkan ada pula yang menolaknya. Sejalan dengan perubahan tersebut diatas masyarakat mempunyai gaya dan cara-cara penerimaan perubahan itu sebagai proses pergeseran pandangan nilai sosial budaya dalam masyarakat yang berjalan secara evoluasi. Penulisan ini tidak mengklarifikasi golongan mana yang salah dan mana yang benar dalam menerima pengaruh sosial budaya tersebut. Tetapi hanya melihat bahwa perbedaan pandangan itu ada dan pasti terjadi setiap periode karena pengaruh budaya. Dengan mengetahuai cara penerimaan dan penanaman pengaruh tersebut kita masing-masing dapat menyesuaikan diri sesuai peranan dan kedudukan kita masing-masing dalam masyarakat, guna menciptakan iklim yang kondusip sejalan dengan perkembangan adat istiadat, budaya serta aturan yang berlaku dalam masyarakat dengan berpedoman: Dimana bumi dipinjak disitu langit dijunjung.
\end{abstract}

\section{Kata Kunci :}

Pergeseran nilai budaya, bumi dipinjak langit dijunjung 


\section{A. Pendahuluan}

Kebinekaan budaya dalam masyarakat Indonesia menunjukkan bahwa perbedaan pandangan hidup dalam masyarakat yang merupakan budaya itu ada. Perbedaan ini dari sumber nenek moyang kita (Koentjaraningrat,1997/4) berasal dari bangsa Austro Melanesoid, golongan ini menduduki daerah Indonesia bagian timur. Seperti kita ketahui masyarakat Indonesia bagian timur yang ada sekarang mempunyai postur tubuh, warna kulit yang berbeda dengan masyarakat di Indonesia barat yang mempunyai ciri-ciri Paleo Mongoloid dari Asia timur. Dari nenek moyang kita sudah ada perbedaan dari asalnya maka perbedaan-perbedaan itu diwarisi oleh anak keturunannya yang menempati wilayah Indonesia yang sekarang. Nenek moyang kita tersebut sejalan perkembangan masyarakat menyebar keseluruh wilayah sehingga tercipta masyarakat berbudaya yang berbeda. Penyebaran penduduk migrasi ini menurut (M . Munandar Soelaeman 1989/115) dapat terjadi secara cepat maupun secara lambat sehingga membutuhkan waktu yang cukup lama. Penyebaran/ perpindahan penduduk ini terus berjalan dengan adanya dua faktor meliputi faktor pendorong dan faktor penarik. Faktor pendorong berasal dari daerah asal dan faktor penariknya berasal dari daerah yang dituju. Faktor tersebut pada umumnya alasan ekonomi, politik, adat istiadat yang berbeda, serta dapat pula bencana alam.

Dalam perjalanan hidup selanjutnya masyarakat Indonesia yang berasal dari 2 (dua) nenek moyang yang berbeda tersebut tetap mempertahankan adat istiadatnya yang telah dijalankan secara turun temurun.

Sebaran penduduk wilayah Indonesia tempo dulu yang terdiri dari beribu-ribu pulau berjalan dengan lambat serta memakan waktu yang cukup lama, perpindahan secara indivisdu maupun secara massal selalu terjadi. Integrasi dengan penduduk setempat dapat pula dilaksanakan, sehingga timbul dan tercipta sifat, karakter, adat istiadat yang bercampur antara satu dengan lainnya serta dibentuk oleh alam dan lingkungan yang berbeda menimbulkan dan melahirkan suku-suku adat istiadat yang berbeda antara satu kelompok dengan kelompok lain, maka timbullah suku-suku yang berada dalam suatu wilayah tertentu.

Sebaran penduduk secara massal mengakibatkan terciptanya pola kelompok dan golongan yang sama adat istiadat merupakan ikatan untuk tergabung menjadi satu kelompok atau golongan, menempati suatu daerah tertentu. Pola kelompok, golongan 
adat istiadat yang sama menjadi faktor memper kokoh dan merupakan ikatan kebersamaan untuk membentuk suatu kelompok dengan identitas yang berbeda dengan kelompok lain, merupakan salah satu faktor pendorong terciptanya suku-suku bangsa. Pengelompokkan atas dasar suku ini pada dasarnya, untuk mempermudah mencari sokongan atau dukungan serta keamanan dan kenyamanan dalam hidupnya.

Kebiasaan dan adat istiadat yang telah dilaksanakan secara turun temurun dan tidak akan hilang bersamaan dengan hilangnya generasi itu, tetapi tetap berjalan sejalan dengan pengaruh budaya yang baru, yang mampu menggeser budaya lama tersebut. Keadaan geografi wilayah Indonesia mempunyai perbedaan antara daerah satu dengan daerah lainnya. Kehidupan manusia sebagai makhluk sosial ditentukan oleh alam (N. Daldjoeni 1997/17) masyarakat yang merupakan kumpulan manusia yang mempunyai adat istiadat tertentu berbeda dengan binatang kehidupannya ditentukan oleh alam. Manusia hanya dapat mempengaruhi alam guna memudahkan untuk memenuhi kebutuhan hidupnya, sifatnya hanya mempengaruhi saja tetapi tidak menentukan, sehingga keadaan alam sangat mempengaruhi pola, gaya, sikap, dan perilaku masyarakat dalam berinteraksi sosial untuk memenuhi kebutuhan hidupnya. Hal ini mengakibatkan dalam satu suku mempunyai karakter dan sifat serta adat istiadat yang berbeda suku Jawa misalnya ada Jawa pesisir utara Tegal, Pekalongan yang mempunyai dialek bahasa yang berbeda dengan suku Jawa pedalaman wilayah Solo, dan Jogya. Demikian pula masyarakat Batak di Sumatra utara (Koentjaraningrat 1997/108) terdiri banyak suku bahkan setiap suku terdiri dari pada beberapa marga, suku Dayak di Kalimantan dan masyarakat yang berdomisili lain dalam wilayah Indonesia .

Perbedaan kebiasaan, adat istiadat dan sikap perilaku budaya menunjukkan identitas tersendiri bagi masyarakat itu, sehingga dapat menimbulkan panatisme terhadap sukunya. "Bahasa menunjukkan bangsa". Tujuan lain yang memberikan gambaran pembagian masyarakat yang dapat dikatakan perbedaan. Penggolongan masyarakat pedesaan dan masyarakat perkotaan.

Masyarakat pedesaan (Munandar Soelaeman 1989/72) yang merupakan suatu persekutuan hidup dan karakter sosial dengan prinsip meliputi

- Adanya hubungan kekerabatan

Pada umumnya masyarakat pedesaan terikat hubungan kerabat, sanak saudara dari satu keturunan keluarga dan mungkin juga terjadi mereka dari satu nenek moyang keturunan mereka. Dengan adanya satu keturunan mereka mempuyai hubungan kekerabatan yang lebih erat. 
- Adanya kedekatan tinggal. Masyarakat pedesaan yang menempati satu wilayah umumnya mempunyai jarak yang cukup jauh dari wilayah pedesaan lain, sehingga dalam satu desa itu mereka pada umumnya bersama - sama menempati wilayah desa itu.

Disamping itu perkembangan dan pembentukan keluarga pada umumnya diarahkan untuk menempati tempat yang berdekatan dengan tempat tinggal orang tua mereka dalam satu wilayah desa.

Ketergantungan mereka terhadap alam kusunya tanah yang merupakan sumber hidup mereka juga merupakan faktor pengikat mereka.

Masyarakat perkotaan yang merupakan masyarakat heterogeen, yang umumnya disebut masyarakat urban, mereka umumnya terdiri dari beberapa pendatang yang dapat meliputi berbagai asal daerah, etnis, suku, agama yang berbeda. Dalam masyarakat perkotaan itu sendiri sudah terjadi perbedaan adat istiadat dan perilaku, serta pandangan budaya.

Dalam tinjaun masyarakat pedesaan dan masyarakat perkotaan sudah pula terjadi adanya perbedaan diantara mereka.

Dalam kehidupan bermasyarakat selanjutnya dengan adanya mobilitas sosial dan interaksi sosial dalam masyarakat akan terjadi, gesekan, singgugan budaya diantara mereka yang dapat mempengaruhi sikap mental dan perilaku mereka.

\section{B. Pergeseran Pandangan Terhadap Sosial Budaya Dalam Masyarakat Sebagai Akibat Pengaruh Kebudayaan}

Seperti yang telah dikemukakan sebelumnya bahwa, nenek moyang kita berasal dari dua induk bangsa yang berbeda dapat saling pengaruh mempengaruhi ataupun mendapat pengaruh dari kebudayaan lain.

Dalam menerima pengaruh tersebut sangat dipengaruhi oleh masyarakat yang menerima dan tata cara mempengaruhi masyarakat yang berkepentingan menanamkan pengaruh meliputi:

1. Pengaruh Hindu Budha

Penanaman pengaruh Hindu. Budha dalam masyarakat menurut (Koentjaraningrat 1997/21) terjadi di Jawa umumnya, sebagian Sumatra dan Kalimantan. Masyarakat Jawa khususnya di pedalaman pengaruh Hindu. Budha dikalangan petani dapat menerima tanpa gejolak yang berarti, timbul pusat pemerintahan kerajaan yang berkembang dengan baik, sampai sekarang masihdirasakan adat istiadat tersebut dalam masyarakat pedalaman. 
2. Pengaruh Kebudayaan Islam

Datnganya pengaruh Islam dalam masyarakat terutama di daerah pesisir yang merupakan daerah perdagangan. Pengaruh Islam di Jawa dengan peran wali songo berjalan lancar. Terjadinya benturan, dan gejolak dalam masyarakat yang kuat terjadi saat pengalihan pusat pemerintahan dari Majapahit ke Demak sebagai pusat siar Islam di Jawa. Kalangan kerajaan Majapahit menganggap runtuhnya kerajaan Majapahit di anggap merupakan tamatnya riwayat kejayaan dunia Majapahit, diwujutkan dengan candra sangkala "Sirna ilang kertaning bumi" yang berarti hilangnya kejayaan bumi Majapahit tahun 1478. Masyarakat Hindu Budha yang tidak dapat menerima pengaruh Islam, mereka menyingkir secara massal membentuk kelompok sendiri menyeberang kepulau Bali, sedangkan yang bertahan membentuk masyarakat Tengger .

Pengaruh kebudayaan Islam terhadap Hindu Budha bagi masyarakat yang mau menerima secara perlahan memadukan budaya Hindu Budha dengan budaya Islam.

Pandangan masyarakat bergeser dari budaya Hindu. Budha kearah nuansa Islam, tidak serta merta, tetapi terjadi secara perlahan. Masyarakat Jawa yang telah mempunyai kebudayaan yang tinggi, antara lain huruf, hari Jawa Pon, Wage, Kliwon, Legi dan Pahing masih tetap digunakan bahkan dipadukan dengan hari Islam Senin, Selasa, Rabu, Kamis, Jum;at, Sabtu dan Minggu berjalan dengan baik. Bahkan Sultan Agung dari Matarm mengadakan perubahan Tarikh Saka Jawa yang sebelumnya berdasarkan peredaran matahari disesuaikan menjadi Tarikh Jawa Islam yang mendasarkan pada peredaran bulan. Perhitungan tahun sakta Jawa yang berasal dari kebudayaan Hindu berdasarkan matahari tahun 0 (nol) sama dengan tahun 78 tahun Masehi yang juga berdasarkan pedoman matahari.

Pada tahun 1633 Masehi sama dengan tahun sakka Jawa 1555 dan tahun 1555 Sakka Jawa tersebut ditetapkan menjadi tahun 1555 Jawa Islam dengan menggunakan dasar perhitungan perhitungan peredaran bulan pada Jum'at legi 1. Suro Tahun 1555 dengan Candra Sangkala Buto Siyung Tata Jalma (Sejarah Kabupaten Madiun 1980/76) pengaruh budaya Islam berjalan beriringan dengan budaya Jawa, pergeseran pandangan ini berjalan secara pelahan. 


\section{Pengaruh Budaya Penjajahan.}

Masyarakat Indonesia yang merupakan masyarakat jajahan Belanda selama 350 tahun dan Jepang 3,5 tahun yang mempunyai sifat karakter dan adat istiadat sendiri juga turut memberikan andil untuk mempengaruhi pandangan nilai sosial budaya yang berlaku pada masyarakat waktu itu, serta sebagian masih dijalankan pada masa sekarang. Pandangan terhadap pendidikan secara umum yang pada tempo dulu dititik beratkan pada pendidikan agama dan dilakukan di Langgar Pondok-pondok yang sifatnya tidak formal, pada zaman Belanda pendidikan dilaksanakan secara formal di sekolah-sekolah dan berjenjang.

4. Pandangan Hidup Masyarakat Indonesia.

Setelah merdeka adalah Pancasila, UUD 1945 yang berasaskan kekeluargaan dan gotong Royong, segingga, sehingga segala tata kehidupan masyarakat, pemerintahan dan kenegaraan selalu berdasarkan pandangan hidup tersebut. Dalam perjalanan sejarah bangsa Indonesia bagi masyarakat yang berbeda pandangan dengan dasar filasafat Negara RI berusaha memberontak, antara lain Kartosuwirdjo, Kaharmuzakar, dan lain-lain bahkan terjadi peristiwa gerakan 30 September 1965 yang berhaluan Komunis. Dengan gagalnya pemberontakan itu ditandai dengan 1 Oktober sebagai hari Kesaktian Pancasila.

Terjadinya refotmasi Tahun 1998 dari orde baru ke orde reformasi pandangan nilai sosial budaya masyarakat mengalami perubahan, baik pemerintahan dan ketata negaraan mengalami reformasi golongan masyarakat yang merasa dirugikan dengan adanya reformasi menuding kaum reformasi adalah golongan anti kemapanan.

Demikian selanjutnya dengan pemerintahan yang bersiafat otonomi daerah menggeser pemerintahan yang bersifat sentralisasasi menjadi pemerintah yang bersifat desentralisasi.

5. Pengaruh ilmu pengetahuan dan teknologi.

Kemajuan ilmu pengetahuan dan teknologi sangat cepat, khususnya teknologi informasi. Perubahan teknologi informasi dapat menembus segala lapisan masyarakat, menembus jarak dan waktu serta medan tanpa batas. Segala kejadian dalam masyarakat dalam waktu yang bersamaan dapat diketahui lewat jaringanjaringan komunikasi, sehingga peristiwa dan, kejadian-kejadian tersebut dapat mempengaruhi pola fikir masyarakat. Informasi penculikan yang terjadi di masyarakat merobah sikap perilaku sebagian masyarakat, yang tempo dulu percaya 
kepada setiap orang di lingkungannya, dengan melihat kejadian tersebut berubah menjadi curiga, tidak percaya kepada sesama, prinsip hati-hati lebih tekankan. Amuk massa, bentrok antara warga memaksakan kehendak lewat kekerasan demo yang anarkhis, yang dilihat lewat jaringan informasi. Pemaksaan kehendak tidak hanya terjadi dikalangan masyarakat bawa tetapi juga terjadi dikalangan elit antara lain anggota DPR, mahasiswa sebagai masyarakat intelek yang harus mengedepankan, pemikiran sistimatis, kreatif ilmiah dan kritis juga dapat bertindak kurang tepat karena pengaruh pihak lain lewat jaringan informasi.

\section{Penutup}

Keaneka ragaman budaya dalam masyarakat timbul karena adanya perbedaan adat istiadat, sikap perilaku, tata krama yang berlaku berbeda dalam masyarakat.

Karena perbedaan tersebut terjadi saling pengaruh mempengaruhi diantara masyarakat.

Mempengaruhi pihak lain diharapkan tidak dengan memaksakan kehendak yang mengakibatkan timbulnya kekerasan.

Perubahan dan pergeseran pandangan nilai sosial budaya itu selalu terjadi, setiap saat karena pengaruh bertujuan untuk perbaikan keadaan berikutnya.

Kecemburuan sosial cemburu terhadap lingkungan sekitar tidak perlu terjadi tetapi dengan mengedapankan prinsip hati-hati dan waspada.

Dikalangan intelektual tumbuhkan rasa kebersamaan, dan mengedepankan musyawarah untuk mufakat dalam menyelesaikan perbedaan 


\section{Daftar Pustaka}

Daldjoeni1997 Dasar-dasar Ilmu Pengetahuan, Sosial Alumni Bandung Koentjaraningrat 1997 Manusia dan Kebudayaan di Indonesia Jambatan Jakarta Sejarah Kabupaten Madiun 1980 Pemerintah Kabupaten Daerah Tingkat II Madiun

Munandar Soelaeman 1989 Ilmu Sosial Dasar Refika Aditama Bandung Naskah Undang-undang Dasar 1945 dan Amandemen I,II,III,IV Pustaka Agung Harapan Surabaya

Soerjono Soekanto 1990 Sosiologi Suatu Pengantar Raja Grafindo Persada Jakarta 